Article

\title{
New Low-Sn Zr Cladding Alloys with Excellent Autoclave Corrosion Resistance and High Strength
}

\author{
Ruiqian Zhang ${ }^{1}$, Beibei Jiang ${ }^{2}$, Chang Pang ${ }^{2}$, Xun Dai ${ }^{1}$, Yongduo Sun ${ }^{1}$, Wei Liao ${ }^{1}$, \\ Qing Wang ${ }^{2, *}$ and Chuang Dong ${ }^{2}$ \\ 1 Science and Technology on Reactor Fuel and Materials Laboratory, Nuclear Power Institute of China, \\ Chengdu 610213,China; zhang_ruiqian@126.com (R.Z.); daixun82@aliyun.com (X.D.); \\ redclupeoid@163.com (Y.S.); liaowei@cnnc.com.cn (W.L.) \\ 2 Key Laboratory of Materials Modification by Laser, Ion and Electron Beams (Ministry of Education), \\ School of Materials Science and Engineering, Dalian University of Technology, Dalian 116024, China; \\ babywhrs@126.com (B.J.); aianor@163.com (C.P.); dong@dlut.edu.cn (C.D.) \\ * Correspondence: wangq@dlut.edu.cn; Tel.: +86-411-8470-8615
}

Academic Editor: Laichang Zhang

Received: 21 March 2017; Accepted: 17 April 2017; Published: 19 April 2017

\begin{abstract}
It is expected that low-Sn Zr alloys are a good candidate to improve the corrosion resistance of $\mathrm{Zr}$ cladding alloys in nuclear reactors, presenting excellent corrosion resistance and high strength. The present work developed a new alloy series of $\mathrm{Zr}-0.25 \mathrm{Sn}-0.36 \mathrm{Fe}-0.11 \mathrm{Cr}-x \mathrm{Nb}(x=0.4 \sim 1.2 \mathrm{wt} \%)$ to investigate the effect of $\mathrm{Nb}$ on autoclave corrosion resistance. Alloy ingots were prepared by non-consumable arc-melting, solid-solutioned, and then rolled into thin plates with a thickness of $0.7 \mathrm{~mm}$. It was found that the designed low-Sn $\mathrm{Zr}$ alloys exhibit excellent corrosion resistances in three out of pile autoclave environments (distilled water at $633 \mathrm{~K} / 18.6 \mathrm{MPa}, 70 \mathrm{ppm} \mathrm{LiOH}$ solution at $633 \mathrm{~K} / 18.6 \mathrm{MPa}$, and superheated water steam at $673 \mathrm{~K} / 10.3 \mathrm{MPa}$ ), as demonstrated by the fact of the $\mathrm{Zr}-0.25 \mathrm{Sn}-0.36 \mathrm{Fe}-0.11 \mathrm{Cr}-0.6 \mathrm{Nb}$ alloy shows a corrosion weight gain $\Delta G=46.3 \mathrm{mg} / \mathrm{dm}^{2}$ and a tensile strength of $\sigma_{\mathrm{UTS}}=461 \mathrm{MPa}$ following 100 days of exposure in water steam. The strength of the low-Sn Zr alloy with a higher $\mathrm{Nb}$ content $(x=1.2 \mathrm{wt} \%)$ is enhanced up to $499 \mathrm{MPa}$, comparable to that of the reference high-Sn N36 alloy (Zr-1.0Sn-1.0Nb-0.25Fe, wt \%). Although the strength improvement is at a slight expense of corrosion resistance with the increase of $\mathrm{Nb}$, the corrosion resistance of the high-Nb alloy with $x=1.2\left(\Delta G=90.4 \mathrm{mg} / \mathrm{dm}^{2}\right.$ for 100-day exposure in the water steam) is still better than that of $\mathrm{N} 36\left(\Delta G=103.4 \mathrm{mg} / \mathrm{dm}^{2}\right)$.
\end{abstract}

Keywords: low-Sn $\mathrm{Zr}$ cladding materials; $\mathrm{Zr}-\mathrm{Sn}-\mathrm{Fe}-\mathrm{Cr}-\mathrm{Nb}$ alloys; mechanical property; corrosion resistance

\section{Introduction}

As fuel cladding and structural materials for commercial nuclear reactors, $\mathrm{Zr}$ alloys exhibit excellent radiation-resistance and good corrosion-resistance and mechanical properties in a neutron reactor environment lower than $623 \mathrm{~K}$ [1-3]. Such alloys with high performance were the main focus in $\mathrm{Zr}-\mathrm{Sn}$ and $\mathrm{Zr}-\mathrm{Nb}$ series [4-10], e.g., Zr-1.0Sn-1.0Nb-0.1Fe (ZIRLO alloy, the number before each element represents the weight percent, wt \%), Zr-1.0Nb-O (M5), Zr-1.2Sn-1.0Nb-0.35Fe (E635), and $\mathrm{Zr}-1.0 \mathrm{Sn}-1.0 \mathrm{Nb}-0.25 \mathrm{Fe}$ (N36). They were generally minor-alloyed with multiple solute elements to achieve the optimum comprehensive properties. In order to further improve the waterside corrosion resistance, several $\mathrm{Zr}$ alloys with a much lower content of $\mathrm{Sn}$ were expected to be developed, such as $\mathrm{Zr}-0.4 \mathrm{Sn}-0.2 \mathrm{Fe}-0.1 \mathrm{Cr}-1.5 \mathrm{Nb}$ (HANA-4) [1] and Zr-0.66Sn-1.0Nb-0.1Fe, modified from ZIRLO alloy [11].

It is emphasized that the mechanical strength and the corrosion resistance of $\mathrm{Zr}$ alloys are closely related to the types and amounts of alloying elements [12-17]. It is difficult to achieve high 
strength and excellent corrosion resistance simultaneously through adding one or two elements since these two requirements are incompatible. For instance, the element $\mathrm{Sn}$ promotes the solid-solution strengthening, while its excessive content could deteriorate the corrosion resistance $[3,11] . \mathrm{Fe}, \mathrm{Cr}$, and $\mathrm{Nb}$ elements are always precipitated from the $\alpha-\mathrm{Zr}$ matrix to form the second phases, such as $\mathrm{Zr}(\mathrm{Fe}, \mathrm{Cr})_{2}$ and $\beta-\mathrm{Nb}$, which can enhance the mechanical properties of alloys at the expense of the corrosion resistance [4-10,18-23]. Actually, different $\mathrm{Fe} / \mathrm{Cr}$ ratios in the $\mathrm{Zr}(\mathrm{Fe}, \mathrm{Cr})_{2}$ phase can also induce different corrosion resistance in the $\mathrm{Fe} / \mathrm{Cr}$-containing $\mathrm{Zr}$ alloys [5]. Thus, for low-Sn $\mathrm{Zr}$ alloys, the contents of other alloying elements should be adjusted to ensure the mechanical properties, as demonstrated by the fact that increasing the Fe content indeed enhances the strengths of $\mathrm{Zr}-1.0 \mathrm{Nb}-x \mathrm{Fe}$ alloy series [24].

By far, the mechanical and autoclave corrosion-resistant properties of $\mathrm{Zr}$ alloys with a much lower Sn content have been seldom reported. Therefore, the present work will aim at developing a new low-Sn $\mathrm{Zr}$ alloy series of $\mathrm{Zr}-0.25 \mathrm{Sn}-0.36 \mathrm{Fe}-0.11 \mathrm{Cr}-x \mathrm{Nb}$, in which the $\mathrm{Nb}$ content is varied and the $\mathrm{Fe}$ and $\mathrm{Cr}$ contents are fixed and referred from the present in-pile N18 alloy (Zr-1.0Sn-0.35Fe-0.11Cr- $0.35 \mathrm{Nb})$ due to the suitable $\mathrm{Fe} / \mathrm{Cr}$ ratio [5]. The microstructural characterization, tensile mechanical property, and autoclave corrosion resistances in three corrosive mediums of the designed alloy series will be performed comprehensively to evaluate the effect of $\mathrm{Nb}$ element on the properties. The high-Sn N36 alloy $(\mathrm{Zr}-1.0 \mathrm{Sn}-0.25 \mathrm{Fe}-1.0 \mathrm{Nb})$ with a higher strength and good corrosion resistance is taken here as the reference alloy. It would be verified that this series of new low-Sn $\mathrm{Zr}$ alloys will possess prominent autoclave corrosion resistances and high strengths.

\section{Experimental Section}

The alloy ingots of the designed low-Sn alloy series of $\mathrm{Zr}-0.25 \mathrm{Sn}-0.36 \mathrm{Fe}-0.11 \mathrm{Cr}-x \mathrm{Nb}(x=0.4,0.6$, 0.8 , and 1.2 , called $\mathrm{Z}-x \mathrm{Nb}$ hereafter), as well as the reference $\mathrm{N} 36$, were prepared by non-consumably arc-melting the mixtures of $\mathrm{Zr}, \mathrm{Fe}, \mathrm{Cr}, \mathrm{Sn}$, and $\mathrm{Nb}$ with a purity of $99.99 \%$ in the Ti-gettered high-purity argon atmosphere. These ingots with a weight of about $50 \mathrm{~g}$ were flipped and remelted at least five times to ensure chemical homogeneity. They were then solid-solutioned at $1323 \mathrm{~K}$ for $0.5 \mathrm{~h}$ under a vacuum condition plus water-quenching. In the following, all the ingots were hot rolled into plates a thickness of $2 \mathrm{~mm}$ at $873 \mathrm{~K}$ eight times, in which the surface of the plates was cut mechanically for the deletion of the oxidation layer. Alloy plates were resealed into a vacuum quartz cube for further heat-treatment at $853 \mathrm{~K}$ for $1 \mathrm{~h}$ and then cold-rolled into thin plates with a thickness of $0.7 \mathrm{~mm}$ three times. Finally, these thin plates were heat-treated at $833 \mathrm{~K}$ for $2 \mathrm{~h}$ under a vacuum condition. All the heat treatments and rolling processing were taken from those for the reference N36 alloy.

Structural identification was performed by the Bruker D8 Focus X-ray diffraction (XRD, Ettlingen, Germany) using the $\mathrm{Cu} K_{\alpha}$ radiation $(\lambda=0.15406 \mathrm{~nm})$, in which the Jade software was used to fit the diffraction peaks [25]. The microstructure morphology and phase verification were carried on with the Philips Tecnai $G^{2}$ transmission electron microscopy (TEM, Amsterdam, the Netherlands) with the selected-area electron diffraction (SAED) analysis, where the TEM samples were prepared by twin-jet electro-polishing in a solution of $12 \% \mathrm{HClO}_{4}+88 \% \mathrm{C}_{2} \mathrm{H}_{5} \mathrm{OH}$ (volume fraction) at $243 \mathrm{~K}$. Tensile tests were performed at room temperature with a strain rate of $3.5 \times 10^{-4} \mathrm{~s}^{-1}$ by using a MTS-810 tensile testing machine (MTS, Cary, NC, USA). The tensile specimens were machined along the rolling direction with a gauge size of $24 \times 4 \mathrm{~mm}$ (length $\times$ width), in which four tensile specimens were prepared for each composition alloy. The autoclave corrosion tests were conducted under three out-of-pile conditions, i.e., distilled water at $633 \mathrm{~K}$ with a pressure of $18.6 \mathrm{MPa}, 70 \mathrm{ppm} \mathrm{LiOH}$ aqueous solution at $633 \mathrm{~K}$ with a pressure of $18.6 \mathrm{MPa}$, and superheated water steam at $673 \mathrm{~K}$ with a pressure of 10.3 MPa, respectively. The specimens for corrosion testing are rectangular with a size of $20 \times 30 \mathrm{~mm}$ and three specimens for each alloy under each condition were prepared, in which the sample surfaces were ground to 1200-grit SiC paper. The corrosion resistance of the specimens was evaluated by measuring the weight gain per unit surface area in relation to the exposure time. 


\section{Results and Discussion}

\subsection{Microstructure Characterization}

The XRD results (Figure 1) show that all the designed $\mathrm{Zr}-0.25 \mathrm{Sn}-0.36 \mathrm{Fe}-0.11 \mathrm{Cr}-x \mathrm{Nb}(\mathrm{Z}-x \mathrm{Nb})$ alloys, as well as the reference N36 alloy, exhibit a single hexagonal $\alpha-\mathrm{Zr}$ structure. The lattice constants were calculated by single-peak fitting the (002), (101), and (102) peaks respectively with the Pearson VII function in Jade, and the average values with errors were listed in Table 1. For further identification of the second precipitated phases, the TEM observations were executed, as shown in Figure 2. It could be found that these precipitated particles are distributed uniformly on the $\alpha$-Zr matrix, and the amount of precipitates increases with the $\mathrm{Nb}$ content from $x=0.4$ to $x=1.2$ (Figure 2a-d). The particle sizes in all these alloys are almost constant, being about $50-100 \mathrm{~nm}$. In the Z-0.4Nb alloy (Figure 2a), the precipitates are scarce, indicating that the alloying elements are almost soluble in the $\alpha$-Zr matrix. While in the other $\mathrm{Zr}-x \mathrm{Nb}$ alloys with $x=0.8 \sim 1.2$, the amounts of the precipitates are relatively higher, more than that in the N36 alloy (Zr-1.0Sn-1.0Nb-0.25Fe) with a high Sn content (Figure 2b-e).

Table 1. Compositions of the designed low-Sn Z-xNb alloy series and the lattice constants of the hexagonal HCP $\alpha$-Zr matrix, as well as their mechanical tensile properties ( $\sigma_{\text {YS }}$ : yield strength, $\sigma_{\mathrm{UTS}}$ : ultimate tensile strength, $\delta$ : elongation to fracture).

\begin{tabular}{|c|c|c|c|c|c|c|}
\hline \multicolumn{2}{|c|}{ Compositions } & \multicolumn{2}{|c|}{ Lattice Constants } & \multirow{2}{*}{$\begin{array}{c}\sigma_{\mathrm{YS}} \\
(\mathrm{MPa})\end{array}$} & \multirow{2}{*}{$\begin{array}{c}\sigma_{\mathrm{UTS}} \\
(\mathbf{M P a})\end{array}$} & \multirow{2}{*}{$\delta(\%)$} \\
\hline (wt \%) & (at \%) & $a(\mathrm{~nm})$ & $c(\mathrm{~nm})$ & & & \\
\hline $\begin{array}{c}\mathrm{Zr}-0.25 \mathrm{Sn}-0.36 \mathrm{Fe}-0.11 \mathrm{Cr}- \\
0.40 \mathrm{Nb}(\mathrm{Z}-0.4 \mathrm{Nb})\end{array}$ & $\mathrm{Zr}_{98.63} \mathrm{Sn}_{0.20} \mathrm{Nb}_{0.39} \mathrm{Fe}_{0.59} \mathrm{Cr}_{0.20}$ & $0.3228 \pm 0.0001$ & $0.5137 \pm 0.0001$ & 365 & 458 & 26.5 \\
\hline $\begin{array}{c}\mathrm{Zr}-0.25 \mathrm{Sn}-0.36 \mathrm{Fe}-0.11 \mathrm{Cr}- \\
0.60 \mathrm{Nb}(\mathrm{Z}-0.6 \mathrm{Nb})\end{array}$ & $\mathrm{Zr}_{98.44} \mathrm{Sn}_{0.20} \mathrm{Nb}_{0.59} \mathrm{Fe}_{0.59} \mathrm{Cr}_{0.20}$ & $0.3229 \pm 0.0003$ & $0.5137 \pm 0.0001$ & 380 & 461 & 18.6 \\
\hline $\begin{array}{c}\mathrm{Zr}-0.25 \mathrm{Sn}-0.36 \mathrm{Fe}-0.11 \mathrm{Cr}- \\
0.80 \mathrm{Nb}(\mathrm{Z}-0.8 \mathrm{Nb})\end{array}$ & $\mathrm{Zr}_{98.24} \mathrm{Sn}_{0.20} \mathrm{Nb}_{0.78} \mathrm{Fe}_{0.59} \mathrm{Cr}_{0.20}$ & $0.3229 \pm 0.0002$ & $0.5146 \pm 0.0001$ & 373 & 456 & 20.2 \\
\hline $\begin{array}{c}\mathrm{Zr}-0.25 \mathrm{Sn}-0.36 \mathrm{Fe}-0.11 \mathrm{Cr}- \\
1.20 \mathrm{Nb}(\mathrm{Z}-1.2 \mathrm{Nb})\end{array}$ & $\mathrm{Zr}_{97.85} \mathrm{Sn}_{0.20} \mathrm{Nb}_{1.17} \mathrm{Fe}_{0.59} \mathrm{Cr}_{0.20}$ & $0.3229 \pm 0.0003$ & $0.5146 \pm 0.0001$ & 425 & 499 & 18.4 \\
\hline $\begin{array}{c}\mathrm{Zr}-1.0 \mathrm{Sn}-0.25 \mathrm{Fe}-1.0 \mathrm{Nb} \\
\text { (N36 (Ref.)) }\end{array}$ & $\mathrm{Zr}_{97.85} \mathrm{Sn}_{0.78} \mathrm{Nb}_{0.98} \mathrm{Fe}_{0.39}$ & $0.3226 \pm 0.0003$ & $0.5137 \pm 0.0001$ & 422 & 489 & 22.3 \\
\hline
\end{tabular}

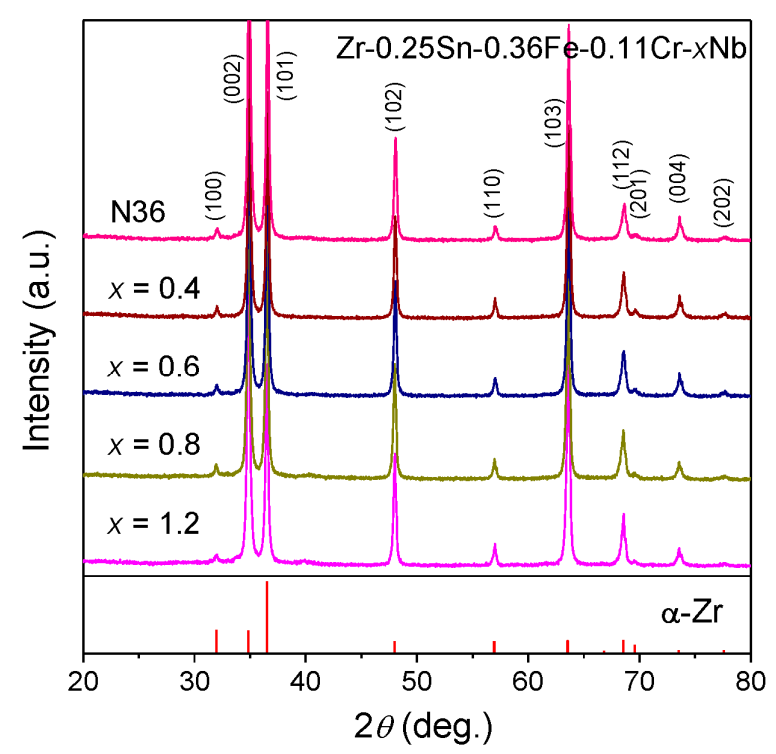

Figure 1. XRD patterns of the designed low-Sn $\mathrm{Zr}-0.25 \mathrm{Sn}-0.36 \mathrm{Fe}-0.11 \mathrm{Cr}-x \mathrm{Nb}(\mathrm{Z}-x \mathrm{Nb})$ alloys and the reference N36. 


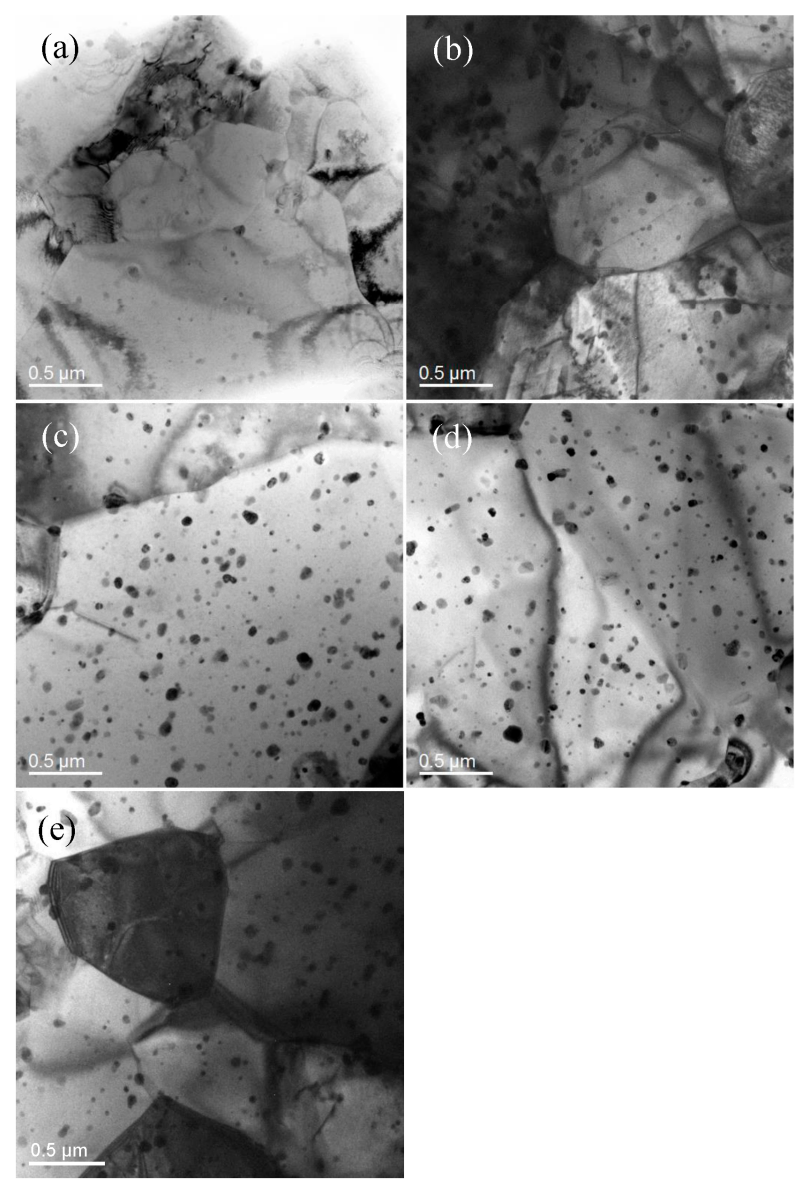

Figure 2. TEM bright field images of the designed $\mathrm{Zr}-0.25 \mathrm{Sn}-0.36 \mathrm{Fe}-0.11 \mathrm{Cr}-x \mathrm{Nb}$ alloys, (a) $x=0.4$; (b) $x=0.6$; (c) $x=0.8$; (d) $x=1.2$; and (e) N36.

The selected-area electron diffraction (SAED) analysis of TEM indicates that on the $\alpha$ - $\mathrm{Zr}$ matrix, the second precipitates are identified as a Laves phase $\mathrm{Zr}(\mathrm{Fe}, \mathrm{Cr}, \mathrm{Nb})_{2}$ with a hexagonal structure. Specifically, Figure $3 a$ gives the TEM results of the $\mathrm{Z}-0.4 \mathrm{Nb}$ alloy with a minor amount of second particles, showing the matrix with a hexagonal structure in $[111]_{\alpha}$ direction (Figure $3 b$ ). The spherical particles in the $\mathrm{Z}-1.2 \mathrm{Nb}$ alloy also exhibit a hexagonal structure, identified as the Laves $\mathrm{Zr}(\mathrm{Fe}, \mathrm{Cr}, \mathrm{Nb})_{2}$ phase by the SAED pattern with the [341] direction (Figure 3c,d). The lattice constants of the precipitates in the Z $-1.2 \mathrm{Nb}$ are $a=0.502 \mathrm{~nm}$ and $c=0.818 \mathrm{~nm}$, respectively, close to those reported values of Laves phases of $\mathrm{Zr}(\mathrm{Fe}, \mathrm{Cr}, \mathrm{Nb})_{2}(a=0.54 \mathrm{~nm}, c=0.87 \mathrm{~nm})$ in the $\mathrm{Zr}-1.6 \mathrm{Sn}-0.6 \mathrm{Nb}-0.2 \mathrm{Fe}-0.1 \mathrm{Cr}$ alloy [18].

According to the lattice constants of the $\alpha-\mathrm{Zr}$ matrix in this $\mathrm{Z}-x \mathrm{Nb}$ alloy series listed in Table 1 , it could be found that the lattice constants ( $a$ and $c$ ) increase gradually with the $\mathrm{Nb}$ content from $x=0.4$ to $x=1$.2. It results from the precipitation of the solutes in the form of intermetallic compound since the atomic radii of all the solutes are smaller than that of $\mathrm{Zr}$, being $R_{\mathrm{Sn}}=0.140 \mathrm{~nm}, R_{\mathrm{Nb}}=0.147 \mathrm{~nm}$, $R_{\mathrm{Fe}}=0.127 \mathrm{~nm}, R_{\mathrm{Cr}}=0.128 \mathrm{~nm}$, and $R_{\mathrm{Zr}}=0.160 \mathrm{~nm}$ [26], respectively. Among them, the atomic radii of $\mathrm{Nb}, \mathrm{Fe}, \mathrm{Cr}$, and $\mathrm{Zr}$ are Goldschmidt radii, while that of $\mathrm{Sn}$ is a covalent radius due to the strong interaction between $\mathrm{Sn}$ and $\mathrm{Zr}$ (larger negative enthalpy of mixing $\Delta H=-43 \mathrm{~kJ} / \mathrm{mol}$ [26]). It was also confirmed by the TEM results that the amount of the second particles in this alloy series increases with $\mathrm{Nb}$ (Figure 2a-d). However, the largest lattice constants ( $a=0.3229 \mathrm{~nm}$ and $c=0.5146 \mathrm{~nm}$ ) of the Z- $-0.8 \mathrm{Nb}$ and Z-1.2Nb alloys are slightly lower than that of pure $\mathrm{Zr}(a=0.3232 \mathrm{~nm}$ and $c=0.5148 \mathrm{~nm}[27])$, implying that a certain amount of solute elements ( $\mathrm{Sn}$ and $\mathrm{Nb}$ ) is still solid-solutioned into the matrix. In comparison, the lattice constants $(a=0.3226 \mathrm{~nm}$ and $c=0.5137 \mathrm{~nm})$ of the reference N36 alloy with a high $\mathrm{Sn}$ is the smallest, smaller than that of the Z- $0.4 \mathrm{Nb}$ alloy, 
which because a much higher content of $S n$ could be soluble in the matrix due to large solubility (about 1.2 wt \%) of Sn in $\alpha-Z r$ [18-20].
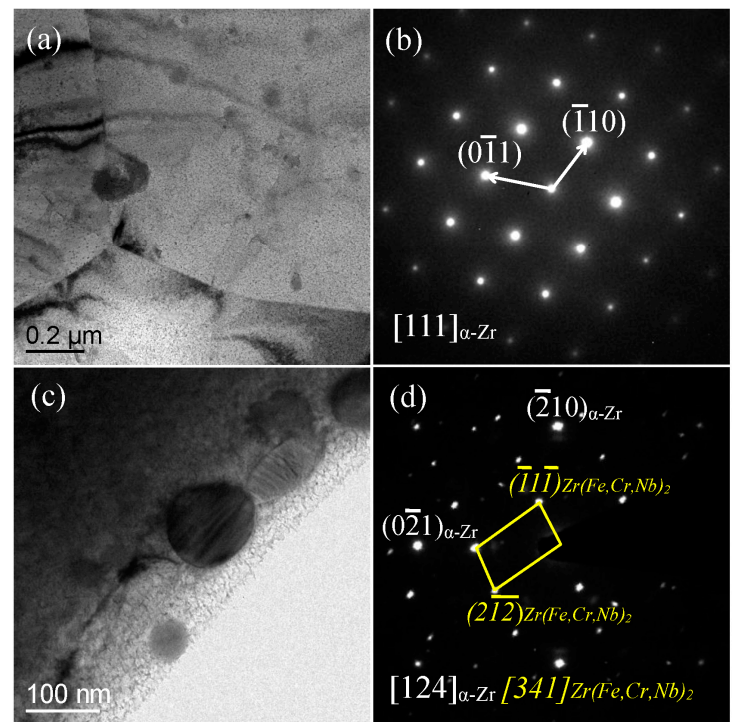

Figure 3. TEM bright field images and SAED patterns of typical serial alloys. (a,b) Zr-0.25Sn-0.36Fe$0.11 \mathrm{Cr}-0.4 \mathrm{Nb}$; and (c,d) Zr-0.25Sn-0.36Fe-0.11Cr-1.2Nb.

\subsection{Mechanical Tensile Properties}

The engineering tensile stress-strain curves of the designed $\mathrm{Z}-\mathrm{xNb}$ alloys and the reference N36 alloy are shown in Figure 4, from which the mechanical property parameters, including the yield strength $\sigma_{\mathrm{YS}}$, the ultimate tensile strength $\sigma_{\mathrm{UTS}}$, and the elongation to fracture $\delta$, could be obtained. All these values are listed in Table 1 . Figure 5 gives the variation tendencies of $\sigma_{\mathrm{YS}}, \sigma_{\mathrm{UTS}}$, and $\delta$ of these alloys with the $\mathrm{Nb}$ content, in which the strengths of $\mathrm{Zr}$ alloys keep at a relatively lower level ( $\left.\sigma_{\text {UTS }} \sim 460 \mathrm{MPa}\right)$ when the $\mathrm{Nb}$ content is not more than $0.80 \mathrm{wt} \%$. The $\mathrm{Z}-0.4 \mathrm{Nb}$ alloy with the lowest $\mathrm{Nb}$ content in this series has the best tensile ductility with $\delta=26.5 \%$. When $\mathrm{Nb}$ increases to $x=1.2 \mathrm{wt} \%$, the alloy strength is enhanced obviously by precipitation strengthening, as demonstrated by the fact that the Z-1.2Nb alloy shows the highest strength with $\sigma_{\mathrm{YS}}=425 \mathrm{MPa}$ and $\sigma_{\mathrm{UTS}}=499 \mathrm{MPa}$, comparable to that of the reference N36 alloy $\left(\sigma_{\mathrm{YS}}=422 \mathrm{MPa}\right.$ and $\left.\sigma_{\mathrm{UTS}}=489 \mathrm{MPa}\right)$ measured under the same condition. It indicates that the increase of $\mathrm{Nb}$ in low-Sn $\mathrm{Zr}$ alloys can also achieve a relatively higher strength. In addition, all of these alloys possess good ductility with the $\delta=18 \sim 27 \%$.

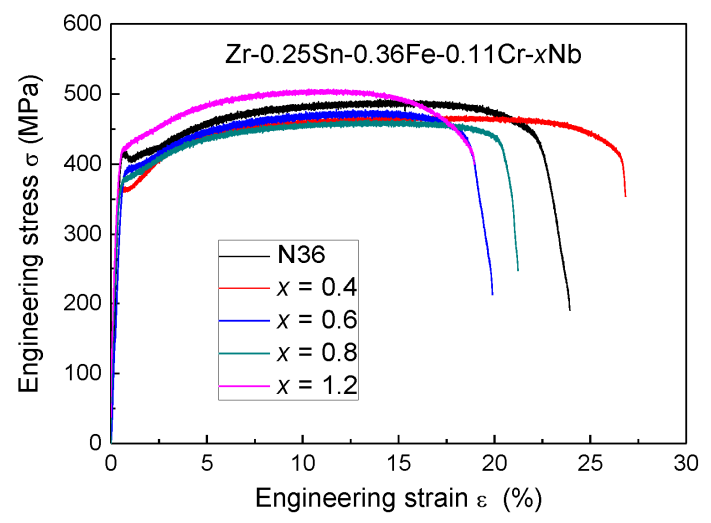

Figure 4. Engineering tensile stress-strain curves of the designed serial $\mathrm{Zr}-0.25 \mathrm{Sn}-0.36 \mathrm{Fe}-0.11 \mathrm{Cr}-x \mathrm{Nb}$ alloys. 


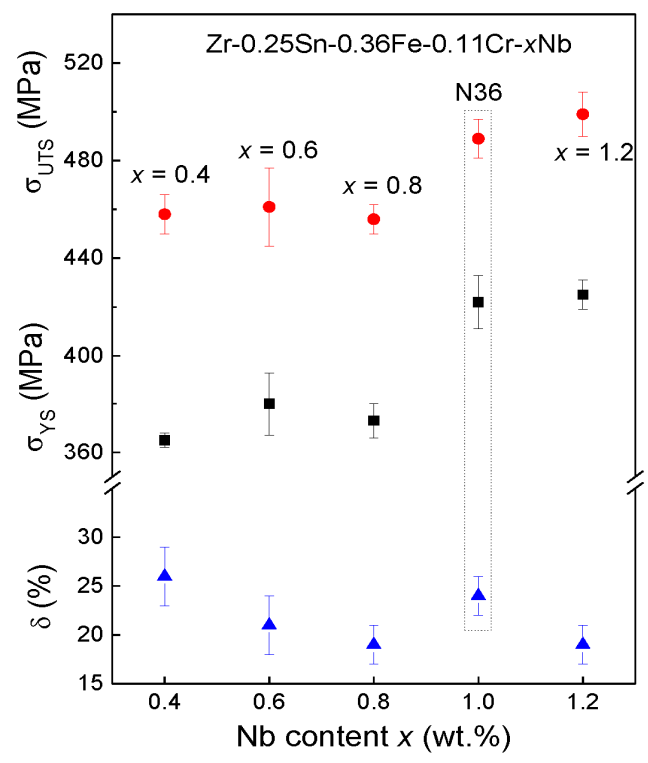

Figure 5. Variations of mechanical properties vs. the $\mathrm{Nb}$ content in the designed low-Sn $\mathrm{Zr}-0.25 \mathrm{Sn}-$ $0.36 \mathrm{Fe}-0.11 \mathrm{Cr}-x \mathrm{Nb}$ alloy series.

\subsection{Autoclave Corrosion Resistances}

In order to investigate the general autoclave corrosion behaviors of the designed low-Sn $\mathrm{Z}-x \mathrm{Nb}$ alloys, the corrosion weight gains of these alloys and N36 were measured in the distilled water at $633 \mathrm{~K} / 18.6 \mathrm{MPa}$, as shown in Figure 6a. It can be seen that the corrosion behaviors of this low-Sn $\mathrm{Zr}$ alloy series change with increasing $\mathrm{Nb}$ content. For the reference N36 alloy with a high content of $\mathrm{Sn}$, the corrosion weight gain $\Delta G$ increases slowly before the 150-day exposure and is then enhanced sharply, as evidenced by the $\Delta G=86.8 \mathrm{mg} / \mathrm{dm}^{2}$ after exposure for 324 days. The corrosion gains of all the designed low-Sn Z-xNb alloys are lower than that of N36. Specially, the Z-xNb alloys with a low $\mathrm{Nb}$ content $(x \leq 0.6)$ exhibit the excellent corrosion resistance, in which the $\Delta G$ s are about $44 \mathrm{mg} / \mathrm{dm}^{2}$ after the 324-day exposure, only half of that of N36. With increasing the $\mathrm{Nb}$ content $(0.8 \sim 1.2 \mathrm{wt} \%)$, the corrosion weight gains of alloys are increased, being $63 \mathrm{mg} / \mathrm{dm}^{2}(\mathrm{Z}-0.8 \mathrm{Nb})$ and $80 \mathrm{mg} / \mathrm{dm}^{2}(\mathrm{Z}-1.2 \mathrm{Nb})$, respectively.

The corrosion behaviors of this low-Sn $\mathrm{Zr}$ alloy series in the $70 \mathrm{ppm} \mathrm{LiOH}$ aqueous solution at $633 \mathrm{~K} / 18.6 \mathrm{MPa}$ (the simulated in-pile hydrochemical condition) follow a similar variation tendency with the $\mathrm{Nb}$ content to that in the distilled water, as shown in Figure 6b. The reference alloy N36 undergoes a corrosion transition at about 125 days of exposure, and then the corrosion gain increases significantly, with a $\Delta G$ of $93.1 \mathrm{mg} / \mathrm{dm}^{2}$ after tested for 283 days. The low-Sn and low-Nb alloys (Z-0.4Nb and Z-0.6Nb) still possess the excellent corrosion resistance with a $\Delta G$ of about $63.5 \mathrm{mg} / \mathrm{dm}^{2}$ for 283-day exposure, which is about $70 \%$ of the N36. The corrosion resistances of the high-Nb alloys $(\mathrm{Z}-0.8 \mathrm{Nb}$ and $\mathrm{Z}-1.2 \mathrm{Nb})$ are inferior to those of the low-Nb alloys, but still better than that of N36, in which the corrosion weight gains are within the range of $72.4 \sim 86.2 \mathrm{mg} / \mathrm{dm}^{2}$ for the 283-day exposure.

In order to further study the uniform corrosion behavior of these designed alloys, the 100-day corrosion tests were carried out in superheated water steam at $673 \mathrm{~K} / 10.3 \mathrm{MPa}$, and the corrosion weight gain curves are shown in Figure 6c. The corrosion rate of the reference N36 was accelerated after the 40 -day exposure, and the $\Delta G$ reached $103.4 \mathrm{mg} / \mathrm{dm}^{2}$ for the 100-day exposure. In comparison, the corrosion resistances of the low-Sn Zr alloys are obviously better than that of the N36. Similarly, the low-Sn and low- $\mathrm{Nb}$ alloys (Z-0.4Nb and Z-0.6Nb) have excellent corrosion resistance with $\Delta G s$ of only about $47.0 \mathrm{mg} / \mathrm{dm}^{2}$ after the 100-day exposure, less than half of that of the $\mathrm{N} 36$. Increasing $\mathrm{Nb}$ would reduce the corrosion resistances, as demonstrated by the fact that the $\Delta G$ of the Z-1.2Nb alloy increases up to $90.4 \mathrm{mg} / \mathrm{dm}^{2}$. 

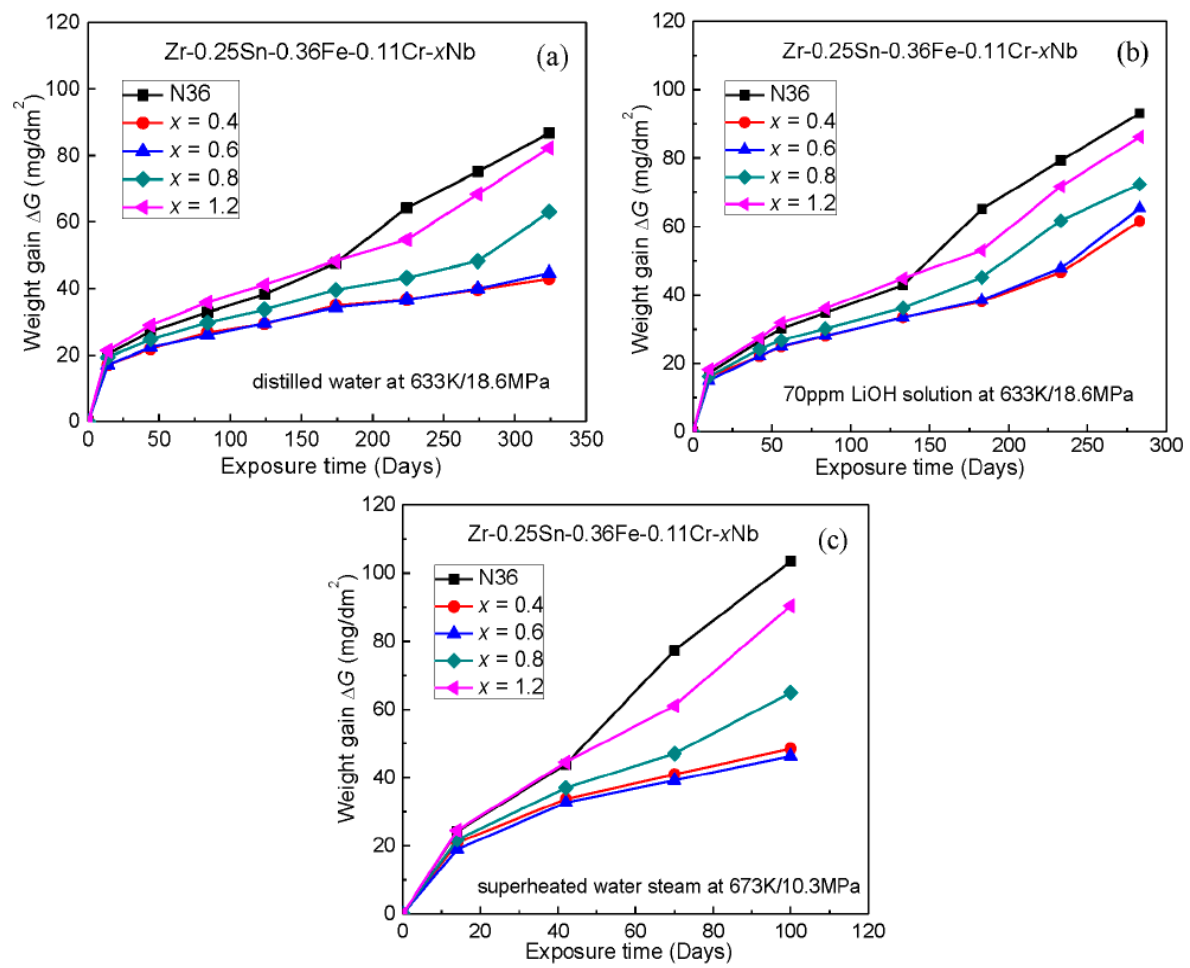

Figure 6. Corrosion behavior of the designed low-Sn $\mathrm{Zr}-0.25 \mathrm{Sn}-0.36 \mathrm{Fe}-0.11 \mathrm{Cr}-x \mathrm{Nb}$ alloys in different out of pile autoclave environments. (a) distilled water at $633 \mathrm{~K} / 18.6 \mathrm{MPa}$; (b) $70 \mathrm{ppm} \mathrm{LiOH}$ solution at $633 \mathrm{~K} / 18.6 \mathrm{MPa}$; and (c) superheated water steam at $673 \mathrm{~K} / 10.3 \mathrm{MPa}$.

Since the variation tendencies of corrosion weight gains $\Delta G$ of the designed low-Sn Z- $x \mathrm{Nb}$ alloys in the present three corrosion environments with the $\mathrm{Nb}$ content are similar, the variation of the $\Delta G$ vs. the $\mathrm{Nb}$ content in the superheated water steam at $673 \mathrm{~K} / 10.3 \mathrm{MPa}$ for 100-day exposure is specially shown in Figure 7a. It could be found that the $\Delta G$ values of these designed alloys increase with the $\mathrm{Nb}$, indicating that the corrosion resistance of these low-Sn alloys would be reduced with the amount of precipitates increasing. Among them, the corrosion gains $\Delta G$ of the $\mathrm{Z}-(0.4 \sim 0.6) \mathrm{Nb}$ alloys are the minimum, about $47.0 \mathrm{mg} / \mathrm{dm}^{2}$ for 100-day exposure. Although the $\Delta G$ of the Z-1.2Nb alloy with a higher $\mathrm{Nb}$ is the maximum $\left(\Delta G=103.4 \mathrm{mg} / \mathrm{dm}^{2}\right)$ in this designed series, it exhibits a better corrosion resistance than the reference $\mathrm{N} 36$ alloy $\left(\Delta G=103.4 \mathrm{mg} / \mathrm{dm}^{2}\right)$.
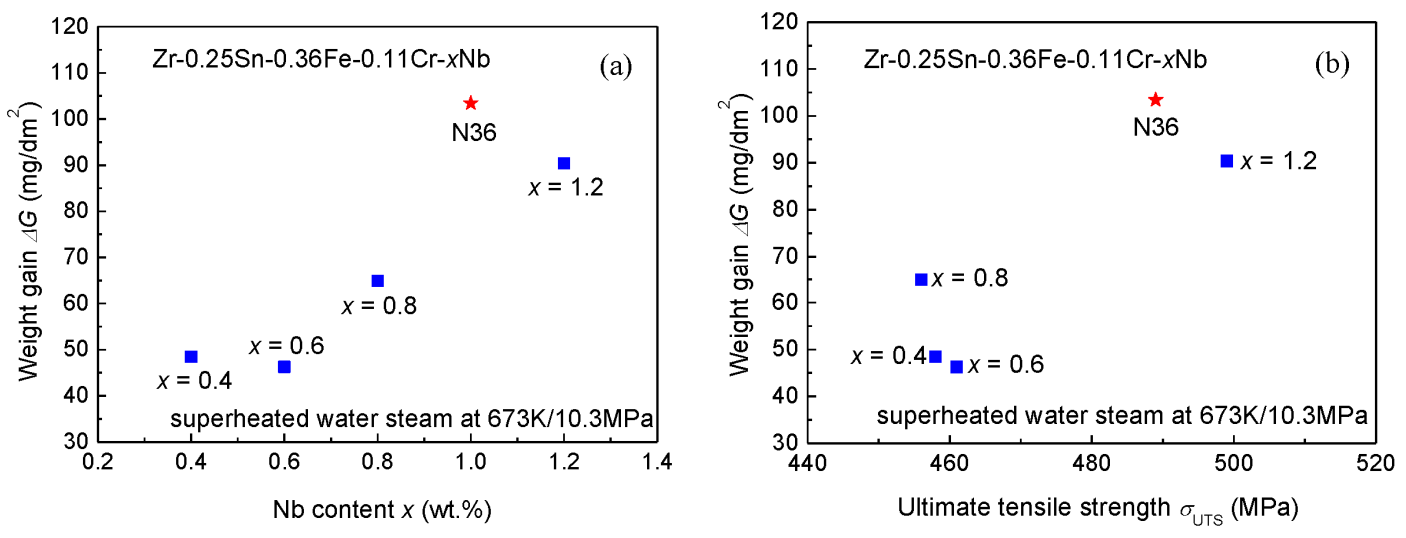

Figure 7. Variation of the corrosion weight gain $\Delta G$ in the superheated water steam at $673 \mathrm{~K} / 10.3 \mathrm{MPa}$ for 100-day exposure vs. the $\mathrm{Nb}$ content (a) and ultimate tensile strength $\sigma_{\mathrm{UTS}}$; (b) of the designed low-Sn Zr-0.25Sn-0.36Fe-0.11Cr- $x \mathrm{Nb}$ alloys. 
Moreover, Table 1 also gives the atomic percent expression of the designed alloys and the reference $\mathrm{N} 36$. It is found that the Z-1.2Nb alloy contains the same content of solute elements ( $2.15 \mathrm{at} \%$ ) as the $\mathrm{N} 36$, as a result that the tensile strengths of these two alloys are comparable strengthened by both solid solution and precipitation [28]. While the better corrosion resistance of the $\mathrm{Z}-1.2 \mathrm{Nb}$ alloy in above three autoclave corrosion environments is due to a much smaller amount of Sn (0.20 at \%) soluble in the $\alpha-\mathrm{Zr}$ matrix, in comparison to that of the N36 alloy containing a high soluble Sn content of 0.78 at $\%[18-20]$.

According to the strength and corrosion resistance of the designed low-Sn Z- $x \mathrm{Nb}$ alloys, as shown in Figure $7 \mathrm{~b}$-being the relationship of the $\sigma_{\text {UTS }}$ with the $\Delta G$ (in the superheated water steam at $673 \mathrm{~K} / 10.3 \mathrm{MPa}$ for 100-day exposure)—-these alloys could be classified into two groups. One group $(\mathrm{Nb} \leq 0.8 \mathrm{wt} \%)$ exhibits the excellent corrosion resistance with a strength level of $\sigma_{\mathrm{UTS}}=460 \mathrm{MPa}$, and the other shows a higher strength $\left(\sigma_{\text {UTS }}=499 \mathrm{MPa}\right)$ and better corrosion resistance than the reference high-Sn N36 alloy (Zr-1.0Sn-1.0Nb-0.25Fe, $\left.\sigma_{\text {UTS }}=489 \mathrm{MPa}\right)$. Furthermore, the corrosion resistances under various environments of these low-Sn alloys are all better than that of the N36.

\section{Conclusions}

A new low-Sn Zr cladding alloy series of $\mathrm{Zr}-0.25 \mathrm{Sn}-0.36 \mathrm{Fe}-0.11 \mathrm{Cr}-x \mathrm{Nb}$ with high strength and excellent corrosion resistance were developed by changing $\mathrm{Nb}$ content $(x=0.4,0.6,0.8,1.2)$. The designed low-Sn alloys exhibit excellent corrosion resistances in three out-of-pile autoclave environments (distilled water at $633 \mathrm{~K} / 18.6 \mathrm{MPa}, 70 \mathrm{ppm} \mathrm{LiOH}$ solution at $633 \mathrm{~K} / 18.6 \mathrm{MPa}$, and superheated water steam at $673 \mathrm{~K} / 10.3 \mathrm{MPa}$ ), as exampled by the $\mathrm{Zr}-0.25 \mathrm{Sn}-0.36 \mathrm{Fe}-0.11 \mathrm{Cr}-0.6 \mathrm{Nb}$ alloy (wt \%) with the corrosion weight gain $\Delta G=46.3 \mathrm{mg} / \mathrm{dm}^{2}$ for 100-day exposure in the superheated water steam environment and with a tensile strength of $\sigma_{\text {UTS }}=460 \mathrm{MPa}$. A large amount of precipitates on the $\alpha-\mathrm{Zr}$ matrix with an increase of $\mathrm{Nb}$ can enhance the strength of these low-Sn alloys up to $\sigma_{\text {UTS }}=499 \mathrm{MPa}$, comparable to that of the reference high-Sn N36 alloy (Zr-1.0Sn-1.0Nb-0.25Fe wt \%, $\left.\sigma_{\mathrm{UTS}}=489 \mathrm{MPa}\right)$. More importantly, all the corrosion resistance of these high-strength and low-Sn alloys (e.g., $\mathrm{Zr}-0.25 \mathrm{Sn}-0.36 \mathrm{Fe}-0.06 \mathrm{Cr}-1.2 \mathrm{Nb}$ with $\Delta G=90.4 \mathrm{mg} / \mathrm{dm}^{2}$ for 100 -day exposure in the water steam at $674 \mathrm{~K} / 10.3 \mathrm{MPa})$ is still better than that of N36 $\left(\Delta G=103.4 \mathrm{mg} / \mathrm{dm}^{2}\right.$ under the same condition).

Acknowledgments: This work was supported by the International Thermonuclear Experimental Reactor (ITER) Program of China [No. 2015GB121004], the International Science \& Technology Cooperation Program of China [No. 2015DFR60370], the Natural Science Foundation of Liaoning Province of China [No. 2015020202], and the Fundamental Research Funds for the Central Universities [No. DUT16ZD212].

Author Contributions: Ruiqian Zhang and Qing Wang conceived and designed the experiments and wrote the paper; Chang Pang and Beibei Jiang performed the experiments and analyzed the data; Xun Dai, Yongduo Sun, and Wei Liao provided assistance in the experiments and contributed reagents/materials; Chuang Dong modified the paper.

Conflicts of Interest: The authors declare no conflicts of interest.

\section{References}

1. Park, J.-Y.; Yoo, S.J.; Choi, B.-K.; Jeong, Y.H. Corrosion and oxide characteristics of Zr-1.5Nb-0.4Sn-0.2Fe-0.1Cr alloys in $360^{\circ} \mathrm{C}$ pure water and LiOH solution. J. Nucl. Mater. 2008, 373, 343-350. [CrossRef]

2. Yao, M.Y.; Zhou, B.X.; Li, Q.; Liu, W.Q.; Geng, X.; Lu, Y.P. A superior corrosion behavior of Zircaloy-4 in lithiated water at $360^{\circ} \mathrm{C} / 18.6 \mathrm{MPa}$ by $\beta$-quenching. J. Nucl. Mater. 2008, 374, 197-203. [CrossRef]

3. Thorvaldsson, T.; Andersson, T.; Wilson, A.; Wardle, A. Correlation between $400{ }^{\circ} \mathrm{C}$ steam corrosion behavior, heat treatment, and microstructure of Zircaloy-4 tubing. In Zirconium in the Nuclear Industry: Eighth International Symposium; Van Swam, L.F.P., Eucken, C.M., Eds.; ASTM International: Baltimore, MD, USA, 1989; pp. 128-140.

4. Kim, H.G.; Jeong, Y.H.; Kim, T.H. Effect of isothermal annealing on the corrosion behavior of Zr- $x \mathrm{Nb}$ alloys. J. Nucl. Mater. 2004, 326, 125-131. [CrossRef]

5. Zhao, W.; Liu, Y.; Jiang, H.; Peng, Q. Effect of heat treatment and $\mathrm{Nb}$ and $\mathrm{H}$ contents on the phase transformation of N18 and N36 zirconium alloys. J. Alloys Compd. 2008, 462, 103-108. [CrossRef] 
6. Sabol, G.P. ZIRLOTM-An Alloy Development Success. In Zirconium in the Nuclear Industry: 14th International Symposium; Ruding, P., Kammenzind, B., Eds.; ASTM International: Bridgeport, CT, USA, 2005; Volume 2, pp. 3-24.

7. Bossis, P.; Pecheur, D.; Hanifi, K.; Thomazet, J.; Blat, M. Comparison of the high burn-up corrosion on M5 and low tin Zircaloy-4. In Zirconium in the Nuclear Industry: 14th International Symposium; Ruding, P., Kammenzind, B., Eds.; ASTM International: Bridgeport, CT, USA, 2005; Volume 3, pp. 494-525.

8. Shishov, V.; Peregud, M.; Nikulina, A.; Kon'kov, V.; Novikov, V.; Markelov, V.; Khokhunova, T.; Kobylyansky, G.; Novoselov, A.; Ostrovsky, Z. Structure-phase state, corrosion and irradiation properties of Zr-Nb-Fe-Sn system alloys. In Zirconium in the Nuclear Industry: 15th International Symposium; Kammenzind, B., Limbäck, M., Eds.; ASTM International: Baltimore, MD, USA, 2009; Volume 5, pp. $724-743$.

9. Yamate, K.; Oe, A.; Hayashi, M.; Okamoto, T.; Anada, H.; Hagi, S. Burnup extension of Japanese PWR fuels. In Proceedings of the 1997 International Topical Meeting on LWR Fuel Performance Conference, Portland, OR, USA, 2-6 March 1997; pp. 318-325.

10. Zhou, B.X.; Yao, M.Y.; Li, Z.K.; Wang, X.M.; Zhou, J.; Long, C.S.; Liu, Q.; Luan, B.F. Optimization of N18 zirconium alloy for fuel cladding of water reactors. J. Mater. Sci. Technol. 2012, 28, 606-613. [CrossRef]

11. Wei, J.; Frankel, P.; Polatidis, E.; Blat, M.; Ambard, A.; Comstock, R.; Hallstadius, L.; Hudson, D.; Smith, G.; Grovenor, C. The effect of $\mathrm{Sn}$ on autoclave corrosion performance and corrosion mechanisms in $\mathrm{Zr}-\mathrm{Sn}-\mathrm{Nb}$ alloys. Acta Mater. 2013, 61, 4200-4214. [CrossRef]

12. Chun, Y.B.; Hwang, S.K.; Kim, M.H.; Kwun, S.I.; Kim, Y.S. Effect of Mo on recrystallization characteristics of Zr-Nb-(Sn)-Mo experimental alloys. J. Nucl. Mater. 1999, 265, 28-37. [CrossRef]

13. Shishov, V.N.; Peregud, M.M.; Nikulina, A.V.; Pimenov, Y.V.; Kobylyansky, G.P.; Novoselov, A.E.; Ostrovsky, Z.E.; Obukhov, A.V. Influence of Structure-Phase State of $\mathrm{Nb}$ Containing Zr Alloys on Irradiation-Induced Growth. In Zirconium in the Nuclear Industry: 14th International Symposium; Ruding, P., Kammenzind, B., Eds.; ASTM International: Bridgeport, CT, USA, 2005; Volume 2, pp. 1-18.

14. Kim, Y.-S.; Kim, S.-K.; Bang, J.-G.; Jung, Y.-H. Effects of $\mathrm{Sn}$ and $\mathrm{Nb}$ on massive hydriding kinetics of Zr-XSn-YNb alloy. J. Nucl. Mater. 2000, 279, 335-343. [CrossRef]

15. Wadekar, S.; Raman, V.; Banerjee, S.; Asundi, M. Structure-property correlation of Zr-base alloys. J. Nucl. Mater. 1988, 151, 162-171. [CrossRef]

16. Pêcheur, D. Oxidation of $\beta-\mathrm{Nb}$ and $\mathrm{Zr}(\mathrm{Fe}, \mathrm{V})_{2}$ precipitates in oxide films formed on advanced $\mathrm{Zr}$-based alloys. J. Nucl. Mater. 2000, 278, 195-201. [CrossRef]

17. Steinbrück, M.; Böttcher, M. Air oxidation of Zircaloy-4, M5 ${ }^{\circledR}$ and ZIRLO ${ }^{\mathrm{TM}}$ cladding alloys at high temperatures. J. Nucl. Mater. 2011, 414, 276-285. [CrossRef]

18. Shen, H.; Peng, S.; Xiang, X.; Naab, F.; Sun, K.; Zu, X. Proton irradiation effects on the precipitate in a Zr-1.6Sn-0.6Nb-0.2Fe-0.1Cr alloy. J. Nucl. Mater. 2014, 452, 335-342. [CrossRef]

19. Liu, W.; Li, Q.; Zhou, B.; Yan, Q.; Yao, M. Effect of heat treatment on the microstructure and corrosion resistance of a Zr-Sn-Nb-Fe-Cr alloy. J. Nucl. Mater. 2005, 341, 97-102. [CrossRef]

20. Hong, H.S.; Moon, J.S.; Kim, S.J.; Lee, K.S. Investigation on the oxidation characteristics of copper-added modified Zircaloy-4 alloys in pressurized water at $360{ }^{\circ}$ C. J. Nucl. Mater. 2001, 297, 113-119. [CrossRef]

21. Lelievre, G.; Tessier, C.; Iltis, X.; Berthier, B.; Lefebvre, F. Impact of intermetallic precipitates on hydrogen distribution in the oxide layers formed on zirconium alloys in a steam atmosphere: $\mathrm{A}^{2} \mathrm{D}\left({ }^{3} \mathrm{He}, \mathrm{p}\right) \alpha$ nuclear analysis study in microbeam mode. J. Alloys Compd. 1998, 268, 308-317. [CrossRef]

22. Toffolon-Masclet, C.; Brachet, J.-C.; Jago, G. Studies of second phase particles in different zirconium alloys using extractive carbon replica and an electrolytic anodic dissolution procedure. J. Nucl. Mater. 2002, 305, 224-231. [CrossRef]

23. Jeong, Y.H.; Kim, H.G.; Kim, T.H. Effect of $\beta$ phase, precipitate and $\mathrm{Nb}$-concentration in matrix on corrosion and oxide characteristics of $\mathrm{Zr}-x \mathrm{Nb}$ alloys. J. Nucl. Mater. 2003, 317, 1-12. [CrossRef]

24. Shishov, V.N. The evolution of microstructure and deformation stability in $\mathrm{Zr}-\mathrm{Nb}-(\mathrm{Sn}, \mathrm{Fe})$ alloys under neutron irradiation. In Zirconium in the Nuclear Industry: 16th International Symposium; Limbäck, M., Barbéris, P., Eds.; ASTM International: Baltimore, MD, USA, 2012; Volume 7, pp. 200-213.

25. Waseda, Y.; Matsubara, E.; Shinoda, K. X-ray Diffraction Crystallography; Springer: Heidelberg, Germany, 2011; pp. 107-127. 
26. Takeuchi, A.; Inoue, A. Classification of bulk metallic glasses by atomic size difference, heat of mixing and period of constituent elements and its application to characterization of the main alloying element. Mater. Trans. 2005, 46, 2817-2829. [CrossRef]

27. Russell, R.B. Coefficients of thermal expansion for zirconium. J. Metals 1954, 6, 1045-1052.

28. Curtis, R.E.; Dressier, G. Effect of thermomechanical processing and heat treatment on the properties of Zr-3Nb-1Sn strip and tubing. In Zirconium in the Nuclear Applications; Schemel, J.H., Rosenbaum, H.S., Eds.; ASTM International: Harrisburg, PA, USA, 1974; Volume 551, pp. 104-128.

(c) 2017 by the authors. Licensee MDPI, Basel, Switzerland. This article is an open access article distributed under the terms and conditions of the Creative Commons Attribution (CC BY) license (http:/ / creativecommons.org/licenses/by/4.0/). 